\title{
EXPERIÊNCIAS POÉTICAS A PARTIR DA CONTAÇÃO DE HISTÓRIAS COM OS KOKAMA NO PARQUE DAS TRIBOS - MANAUS
}

\section{POETIC EXPERIENCES FROM STORYTELLING WITH KOKAMA IN THE PARQUE DAS TRIBOS - MANAUS}

\author{
Vanessa Benites Bordin \\ vbordin@uea.edu.br \\ Universidade do Estado do Amazonas - UEA
}

\begin{abstract}
Resumo:
Este artigo apresenta uma reflexão sobre a pesquisa realizada no campo das práticas pedagógicas e experiências poéticas vividas junto aos indígenas da etnia Kokama. Que se pautaram pela busca de diálogo com os saberes ameríndios e a criação de um espaço de conhecimento e de trocas culturais que potencializa as vozes dos sujeitos envolvidos - os indígenas, os alunos-performers e a performer-professora a partir do projeto de extensão desenvolvido na Universidade do Estado do Amazonas intitulado 'Contadores de Histórias: o teatro popular de formas animadas na comunidade'. Ocorridos junto à comunidade indígena Parque das Tribos localizada no perímetro urbano da cidade de Manaus, no Espaço Cultural assessorado pela Gerência de Educação Escolar Indígena (GEEI/SEMED): o Centro Cultural Mainuma.
\end{abstract}

Palavras-chave: contação de histórias, performance, saberes ameríndios.

\section{Abstract:}

This article presents a reflection on the research carried out in the field of pedagogical practices and poetic experiences lived with the Kokama indigenous people. That were guided by the search for dialogue with Amerindian knowledge and the creation of a space of knowledge and cultural exchange that enhances the voices of the subjects involved - the indigenous people, the studentperformers and the performer-teacher from the extension project developed at the State University of Amazonas entitled 'Storytellers: popular theater in animated ways in the community'. Occurring with the Parque das Tribos indigenous community located in the urban perimeter of the city of Manaus, in the Cultural Space assisted by the Management of Indigenous School Education (GEEI / SEMED): the Mainuma Cultural Center.

Keywords: storytelling, performance, amerindian knowledge.

\section{O corpo-memória na performance de contar histórias}

O fato que me leva a buscar outras áreas de conhecimento como referência para este trabalho, como a antropologia, a linguística e a educação, sabendo que são áreas em que minha competência é limitada, se dá no desejo de tentar esclarecer algumas questões dentro do meu próprio campo de pesquisa. Me aproprio do pensamento de autores inseridos nessas diferentes 
áreas porque me inscrevem nos campos inter/trans disciplinares, onde conecto as similaridades encontradas em seus trabalhos.

Assim, falar em contação de histórias como performance pode se fundamentar a partir de diferentes áreas de conhecimento que se complementam, principalmente por trazerem a ideia de corporalidade como fundamento central.

Para contar uma história, antes, é preciso conhecê-la, ouvi-la, o que requer uma abertura em relação ao outro, ouvindo-o de maneira interessada. Observo que na maioria das vezes existe uma dificuldade na comunicação que diz respeito à escuta, ao invés de focarmos no que o outro está falando, antes dele acabar sua fala já estamos pensando no que nós (eu) vamos falar, o que impede uma reação e troca espontâneas. Importante destacar que nas reuniões que participo com as mulheres indígenas existe o momento em que cada uma fala, sem que ninguém interrompa a fala da outra, e após todas falarem elas ficam em silêncio por alguns minutos.

No início achava estranho, pensava: será que ninguém vai falar nada? será que devo tomar a iniciativa? Então, Mepaeruna, indígena da etnia Tikuna, me disse que funciona assim: é colocada a pauta do debate e em seguida se dá um tempo para a reflexão individual de cada uma sobre o assunto: 'primeiro pensa, depois fala, e tem que ser uma de cada vez'. Existe um tempo para que o que foi dito seja processado por aquela que escuta, esse tempo é importante para que as resoluções não sejam tomadas precipitadamente.

Este relato pode ser pensado a partir do que Paul Zumthor (2002) diz a respeito da relação entre emissor da voz e receptor auditivo. O historiador e linguista nos fala que o encontro entre aquele que fala e aquele que escuta, gera uma troca que leva à compreensão, uma compreensão que é de cada um, e essa compreensão está relacionada ao prazer da experiência. Uma experiência que envolve todas as funções da percepção: “(ouvido, vista, tato...), a intelecção, a emoção se acham misturadas simultaneamente em jogo, de maneira dramática” (ZUMTHOR, 2002, p. 59). Assim, o corpo dos dois (do emissor da voz e do receptor auditivo) é modificado durante essa troca, que se dá em um contexto circunstancial e sociológico único. Portanto, o corpo é a materialização daquilo que é próprio do indivíduo, da realidade que se vive, e é através dele que nos manifestamos, nos relacionamos com o mundo e construímos conhecimento.

Com efeito, a importância do trabalho de Zumthor também está em quebrar com algumas dicotomias, como a relação corpo e voz, muito cara aos profissionais das artes cênicas. Considera a 
voz, não separada do corpo, mas como qualidade de emanação do corpo, representando-o sonoramente de maneira plena, fazendo com que através da voz o sujeito atravesse o limite do seu próprio corpo, mas sem rompê-lo, na medida em que possibilita uma interação com o outro que habita o campo da linguagem.

Do mesmo modo, a professora-pesquisadora e contadora de histórias Luciana Hartmann $(2011)^{1}$, utiliza o conceito de performance para falar do ato de contar histórias colocando o foco no corpo. A performance daquele que conta seria a forma dada aquilo que é contada. Em seu trabalho a respeito dos contadores de causos da fronteira entre Brasil, Argentina e Uruguai, observa a relação entre corpo e experiência durante as performances narrativas deles, onde as marcas do corpo funcionam como memória.

Elisabeth Silva Lopes (2010), também vai falar da performance da memória, dizendo que o corpo é o espaço da memória do performer, desta maneira, a memória funciona como um procedimento performativo produzindo um discurso que tem uma função pedagógica e histórica. De sua prática como diretora percebe que a noção de sujeito, no trabalho com as memórias pessoais, se amplia para o performer, pois ele não é um sujeito único, mas reflexo dos vários discursos de 'outros' perpassados por processos históricos e pessoais.

Nas artes cênicas, a partir dos estudos da performance, Richard Schechner (2004) atenta para a necessidade de se estudar a performance para além do campo da performance arte, pensando-a enquanto performance cultural que inclui a teatralidade do cotidiano e de rituais de diferentes sociedades, das questões de gênero, das manifestações da cultura popular, preparando professores e artistas da cena em outros âmbitos, para além das formas tradicionais de teatro e dança ocidentais.

Neste trabalho, a performance do ato de contar histórias nos ajuda a estabelecer relações com as professoras e as crianças indígenas da comunidade indígena Parque das Tribos em Manaus, Amazonas, no Espaço Cultural assessorado pela Gerência de Educação Escolar Indígena (GEEI/SEMED): o Centro Cultural Mainuma ${ }^{2}$. Através da memória ativamos histórias dos antepassados e histórias pessoais que nos permitem criar experiências sensíveis nesses espaços de encontros poéticos.

\footnotetext{
${ }^{1}$ Que também traz a referência de Paul Zumthor em seu trabalho.

${ }^{2}$ Beija-Flor na língua Kokama.
} 
Deste modo, devido à características como estas relacionadas a elementos simbólicos ligados à memória, à corporeidade e a não distinção entre arte e vida, já que tudo flui de maneira mais orgânica, mesmo que existam momentos como os rituais que acontecem de forma organizada e dentro de uma estrutura pré-estabelecida pertencente a um sistema simbólico, eles possuem um significado de existência e relação com o ciclo da vida para as pessoas daquele povo, que - nós artistas - nos identificamos com suas práticas cotidianas e ritualísticas, buscando analogias com o nosso fazer artístico.

A ideia do corpo como constituinte central nas sociedades ameríndias da América do Sul é um conceito chave para começarmos a nos familiarizar com sua realidade e visão de mundo. Para tanto, temos como introdutório o estudo feito pelos antropólogos Eduardo Viveiros de Castro, Anthony Seeger e Roberto Da Matta $(1979$, p.2) em que falam: “que a originalidade das sociedades tribais brasileiras (de modo mais amplo, sul-americana) reside numa elaboração particularmente rica da noção de pessoa, como referência especial à corporalidade enquanto idioma simbólico focal."

A noção de 'pessoa' é sustentada a partir de um pensamento coletivo em que todas as espécies possuem um fundo humano universal em si, e se definem a partir da complementação do olhar do outro, onde o corpo é uma matriz simbólica que ocupa um lugar central para o entendimento da natureza humana. Essa maneira ameríndia de percepção do mundo, Eduardo Viveiros de Castro $(1996,2015)$ vai denominar de 'perspectivismo'. Deste modo, a ideia de corpo não se dissocia da ideia de pessoa, que está relacionada a um contexto, e o corpo vai sendo construído ao longo da trajetória de vida de cada um.

Esse corpo está ligado ao conceito de saber, o 'saber do corpo', como ideia de aprendizagem no mundo ameríndio. Trago este conceito a partir do estudo da antropóloga Els Lagrou (2007) baseada em sua experiência com o grupo indígena Kaxinawa da região do Acre da Amazônia. Lagrou diz que na cultura ameríndia o conhecimento não se acumula fora, ele é construído a partir do próprio sujeito e de suas relações com o outro e a natureza.

O conceito de conhecimento 'encorporado' Els Lagrou remete aos estudos de Eduardo Viveiros de Castro, dizendo que para o ameríndio o aprendizado é 'encorporado' e sempre se renova a partir de suas experiências. A palavra 'encorporar' é utilizada por Viveiros de Castro que acredita ser a melhor forma de tradução encontrada para expressar essa ideia: "Traduzo a forma inglesa to 
embody e seus derivados, pelo neologismo 'encorporar' visto que nem 'encarnar' nem 'incorporar' são realmente adequados." (1996, p. 136). Deste modo, o corpo revela aquilo pelo qual é afetado. Diana Taylor (2013) - dentro desse entendimento do 'saber do corpo' - traz o conceito de embodiment traduzido por incorporar ${ }^{3}$ e relacionando-o ao conceito de repertório que, diferente do arquivo que se refere à hegemonia da escrita como única fonte de pesquisa valorizada, remete justamente ao que não está escrito, documentado, mas se revela por ações, num gesto de descolonização do saber, em que a escrita tem papel predominante na dita cultura 'culta' em forma de arquivo. Assim, o arquivo estaria relacionado à cultura letrada e o repertório à cultura não letrada. O que é interessante de sua reflexão para este trabalho, é que ela questiona que culturas serão eternizadas e que culturas podem ser esquecidas devido a perpetuação do registro, que tem a necessidade de armazenar o conhecimento escrito para uma provável consulta posterior. Já o repertório está nas performances do corpo, do efêmero, daquilo que vivemos.

Por termos uma relação muito forte com o 'saber do corpo' nas artes cênicas nos identificamos com práticas de diferentes culturas que se afirmam nesse sentido, principalmente de culturas tradicionais que têm essa característica intrínseca, devido ao senso de coletividade inerente à elas, diferente de nossa sociedade capitalista, que alimenta a competitividade tornando-nos individualistas. É pelo corpo, pelo fazer, que desenvolvemos processos de criação artística e de ensino da arte, sempre buscando referências teóricas que nos ajudem a compreender, transformar e (acredito) melhorar esse fazer.

Ao longo de meu processo de ensino de artes cênicas busco, em minha atuação, fazer junto. Na docência, a presença e os recursos pedagógicos e criativos da contadora de histórias servem como estímulo da prática coletiva. Esta prática não é encenada para que me imitem, mas para envolvê-los, fazendo com que se engajem no trabalho, criando um espaço de encontro onde trocamos conhecimento sensível e poético. Usando meu corpo em performance a comunicação se torna mais efetiva e afetiva, especialmente na experiência com crianças. Percebo que a forma de ensinar-aprender dos indígenas se delineia por esse caminho - como tenho experienciado - em um

\footnotetext{
${ }^{3}$ Apesar de Viveiros de Castro propor como grafia a palavra 'encorporar', é uma forma escrita que foi substituída por incorporar. Dicionário on-line de português: https://www.dicio.com.br/encorporar/ (acesso: 28/10/2019). No caso dos trabalhos de Viveiros de Castro e Taylor, o 'encorporar' ou 'incorporar' tem o mesmo sentido de práticas relacionadas a corporeidade.
} 
espaço de encontro coletivo, de comunhão, onde não são dadas muitas explicações, ou se mostra como fazer, mas se faz junto, motivando o desejo do aprendizado.

\section{Contando histórias, conhecendo tradições}

UMA HISTÓRIA ANTIGA

O mundo nasce quando nasce Kémarin, o primeiro homem Kokama, filho de uma mulher muito boa e de Kémari, Deus Kokama que de pomba virou anjo. Os primeiros tsumi, xamãs ayahuasqueiros, passaram o conhecimento da existência de cinco sóis (Kuarachi) mundos ou espaços - chamam sol porque o sol transpassa tudo.

Wepe Kuarachi, é o primeiro sol ou primeiro mundo, que fica debaixo da água, lá vive a Mãe d'água, ela é dona deste espaço e decide quando acontecerá a crescente e vazante dos lagos, rios e riachos. Neste espaço há uma enorme Mui Watsu (cobra grande) que segura os cinco mundos e faz bolhas no mundo dos peixes, ela é acompanhada pela Onça Preta, a Mãe das Arraias e a Mãe dos Tracajás que seguram Mui Watsu para que ela não saia, senão haverá grandes redemoinhos e desastres nos outros mundos.

Wepe Mukuika, é o segundo sol, onde vivem os peixes, lagartos, botos, tracajás, jabutis e jacarés. A dona da água é Ipira Mama, com seus cabelos compridos e seu canto penetrante, ela se relaciona com os ikuan (curandeiros) e os

payun (feiticeiros) transmitindo mensagens boas e ruins para cheguem até as pessoas.

Mutsapirika kuarachi, o terceiro sol, é onde vive o povo Kokama com suas plantas, animais, seres naturais, curandeiros e seres espirituais. Quando querem semear, pescar ou caçar pedem permissão aos donos ou espíritos que vivem na mata, na montanha, na água, na terra e nas árvores. $\mathrm{O}$ dono deste mundo, que cuida de todos os habitantes, é twirati Mama, a Mãe da Mata. Ela não gosta que mexam com suas crias, que são as árvores e todas as outras plantas que existem, quando isso acontece, ela chama a Mãe do Vento e a Mãe da Chuva para atacar as pessoas. Às vezes, também se apresenta disfarçada de pessoa para distrair quem está nas matas, impedindo quem esteja com más intensões, fazendo com que errem o caminho.

Irakua kuarachi, é o quarto sol, nesse espaço vivem as almas que se relacionam com o xamã ayahuasqueiro. As almas dos mortos bons vivem em casas entre flores, estrelas e pássaros, sobre o cume das montanhas, já os mortos maus são queimados e suas cinzas formam as nuvens do céu.

Pichka kuarachi, o quinto sol, é onde vive o Deus Iwatin Papa e Kémari, o Deus Kokama que era uma pomba e se transformou em um anjo. Mais abaixo se encontram colinas e um pouco acima no meio das colinas vive o Uruputini Mama, chefe de todas as aves da terra. Neste mundo é onde estão Yatsí (a lua) e mais acima Kuarachi (o sol) que ilumina todos os mundos. ${ }^{4}$

Esta história fala sobre como se constitui o universo a partir da visão do povo indígena Kokama. Para os Kokama existem cinco mundos, ou sóis, já que o sol é o grande astro que perpassa todos os mundos. tminua imintsara Kuarachi Kokama é como denominam suas histórias, que chamam de antigas, pois vêm de tempos imemoriais transmitidas por seus antepassados. Essas histórias representam um de seus modos de produção de conhecimento, difundindo costumes e

\footnotetext{
${ }^{4}$ Trago aqui uma adaptação do mito de criação do mundo Kokama a partir do material didático fornecido para o ensino da língua Kokama. RUBIM, Altaci Corrêa. Yawati Tinin. Brasília: Lexterm, UnB, 2015. Edição bilíngue: Kokama e Português. Essa história foi interpretada e adaptada para a escrita do Kokama no Brasil por Altaci Corrêa Rubim/SEMED/PCSA/LEXTERM/UnB. Também ouvi a versão de Dona Raimunda Kokama que me ajudou na adaptação.
} 
saberes de seu povo, é através delas que compreendem algumas questões sobre o que existe no universo e como se relacionar com elas. São histórias que abordam aspectos que representam suas relações com a natureza e com o mundo espiritual a partir da experiência.

Foi Tsuni, professora indígena Kokama, quem sugeriu que eu aprendesse e contasse para os alunos dela esta história sobre os mundos na visão Kokama. Em uma das primeiras vezes que participei de suas aulas de língua Kokama, no Centro Cultural Mainuma, eu havia performado algumas histórias com seu grupo de alunos, e Tsuni achou que seria interessante eu contar do 'meu jeito' aquela história que pertence ao seu povo. Disse que gosta como eu conto, fazendo as personagens de uma maneira 'engraçada' e sem precisar ler. Assim, utilizo alguns momentos de encenação, mas não adapto de forma dramatúrgica, mantenho a essência da narrativa que li, ou, ouvi e moldo às necessidades do espaço, desfrutando do recurso da improvisação que me auxilia no jogo com os diferentes públicos.

Em minhas performances como contadora de histórias não trabalho com um texto decorado, fixo. Memorizo a narrativa lendo-a diversas vezes, ensaiando diferentes maneiras de contá-la, reconstruindo a história à minha maneira, às vezes, suprimindo algumas palavras e substituindo-as por ações, percebendo quais devem ser mantidas e quais precisam ser repetidas para que a história não perca seu sentido. Depois, quando encontro pessoas com quem compartilho essas narrativas, improviso a partir da relação que estabeleço com esses ouvintes, respeitando o roteiro da história que já está estruturado com base no que trabalhei individualmente.

Quando estou na posição de ouvinte/aprendiz, conhecendo uma história, preciso prestar atenção, não só no conteúdo da fala do outro, mas em cada detalhe de suas ações que geram as imagens da narrativa. E quando estou contando uma história, busco que ela sensibilize o espectador para que possamos juntos construir as imagens da narrativa. Deste modo, o espectador não está passivo nessa troca, ele é fundamental no processo, afinal, o contar histórias só faz sentido se tiver alguém para ouvi-las.

Portanto, quando falo em improvisar, me refiro a essas trocas estabelecidas com o outro, a partir de suas reações que proporcionam estímulos que me afetam e consequentemente transformam minha performance no 'aqui e agora'.

As imagens que se constroem dessa relação entre quem conta e quem escuta são da ordem do virtual, pois se revelam através dos sentidos, inerentes à memória corporal de cada um, como 
fala Zumthor (2002). Assim, me concentro em perceber a entonação, a sonoridade, o ritmo, a forma, o desenho da voz daquele que conta, sua respiração, sua gestualidade, como se constroem os momentos de silêncio, de pausa, de suspensão e de fechamento (conclusão ou não da narrativa).

Para que eu contasse a história dos mundos Kokama, Tsuni me emprestou o material didático bilíngue de ensino da língua Kokama que utiliza em aula: Yawati Tinin (Jabuti Branco), elaborado pela professora indígena Kokama Altaci Corrêa Rubim, que além de ter produzido vários volumes desse material, desenvolve pesquisas nas áreas linguísticas e educacionais a respeito de seu povo. Rubim (2016) fala sobre a questão da memória coletiva na tradição oral, passada de geração a geração pelos mais velhos, como uma característica dos saberes Kokama.

As histórias e canções que constam no material didático fazem parte de uma pesquisa extensa em materiais Kokama produzidos no Peru, na Colômbia ${ }^{5}$ e da experiência em campo nas aldeias e comunidades Kokama do Amazonas, onde existem falantes plenos da língua e idosos conhecedores dos saberes tradicionais de seu povo. Tsuni utiliza esse material como o principal suporte de suas aulas. Ela também conhece muitas histórias que aprendeu com a sua avó e com o seu pai. E conta com os ensinamentos de Dona Raimunda Kokama, a mais antiga moradora do Parque das Tribos, falante da língua e com um vasto conhecimento sobre ervas medicinais, histórias, canções e produção de utensílios domésticos.

Depois que li a versão em português que Tsuni me emprestou, encontrei a versão em espanhol e conversei com Dona Raimunda para saber mais detalhes da história e compreender algumas questões. Então, percebi que havia elementos diferentes em cada versão que não modificavam a estrutura da história, mas, acrescentavam informações, ou, pelo modo como eram contadas me faziam entender melhor.

Sempre procuro fazer uma adaptação que se aproxime do meu jeito de falar, se encontrei a história escrita busco outras versões para ler, se ouvi de alguém peço para que me conte novamente, o que é interessante pois a pessoa nunca vai contar exatamente igual, ou, procuro outra pessoa que conheça a história para saber sua versão.

Assim, vou experimentando, criando e transformando a contação de histórias até torná-la orgânica para mim enquanto atriz-performer. Por isso o processo de busca pessoal é tão importante no caminho de formação do ator-performer e do artista-professor, pois é através dessas

\footnotetext{
${ }^{5} \mathrm{O}$ povo Kokama vive em comunidades no Brasil, Peru e Colômbia, principalmente na região da tríplice fronteira.
} 
experimentações individuais, em que nos conectamos com nós mesmos, que vamos liberando nossas energias criativas e alcançando a organicidade.

Para complementar a narrativa utilizo canções e instrumentos musicais em minhas criações, eles proporcionam sonoridades que valorizam determinados momentos da história, ajudam na construção das personagens e me auxiliam como um tempo de pausa no uso da voz, um instante de descanso para recuperar o fôlego, o que é bastante útil, principalmente quando intervenho em espaços abertos que preciso de muita projeção, e quando há bastante interação dos presentes.

Aliados de minha criação são alguns objetos cênicos que funcionam como estímulos durante as experimentações. Seleciono adereços variados de acordo com a história, eles contribuem na identificação e diferenciação das personagens, favorecendo a realização de algumas ações que acontecem durante a narrativa. Muitas vezes, utilizo bonecos e máscaras que se apresentam como personagens ou como contadores de histórias ao meu lado.

O figurino que utilizo é uma saia na cor neutra de tecido liso cru, com bolsos grandes onde guardo os objetos cênicos e os instrumentos musicais, que podem ser de cores e texturas variadas. Essa saia me acompanha nas contações de histórias desde 2007, quando eu e a artista-professora, Jordana de Moraes, apresentamos nossa montagem cênica de formatura em Artes Cênicas ${ }^{6}$, feita para a rua?.

Hoje, a saia possui grafismos Kokama. Quando os adolescentes indígenas da turma de Tsuni souberam que eu iria contar a história sobre os mundos Kokama sugeriram que minha saia fosse pintada com os grafismos, que, segundo eles, a deixaria mais bonita e combinaria com a história. Eu aceitei, então os adolescentes desenharam os grafismos e agora a saia por si só conta uma história, uma história que eles são os autores.

\footnotetext{
${ }^{6}$ Bacharelado em Interpretação Teatral pela Universidade Federal de Santa Maria (UFSM), Rio Grande do Sul.

${ }^{7}$ Falo rua me referindo a espaços públicos abertos de fluxo de pessoas: praças, parques, calçadões, esquinas etc. 

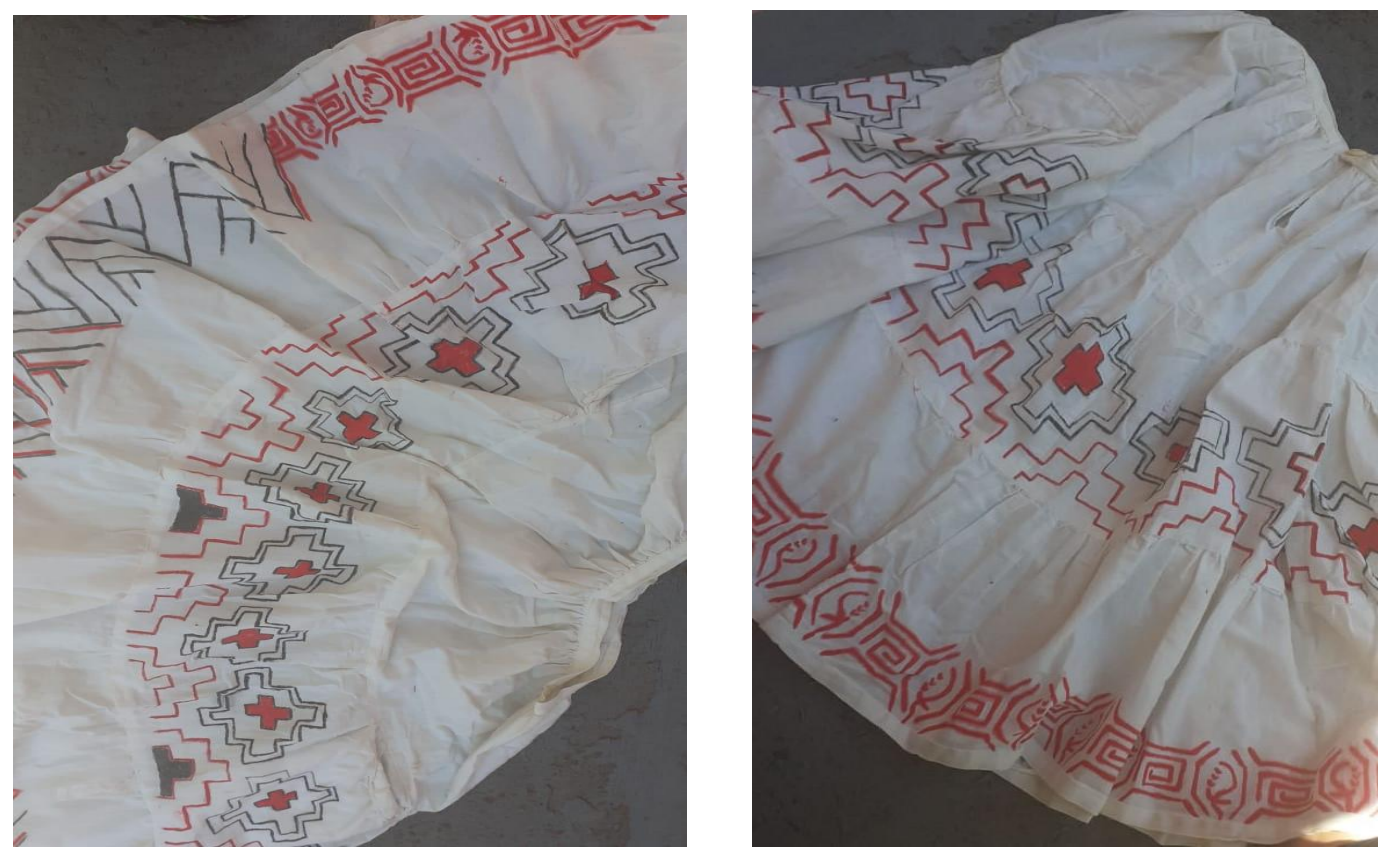

Figura 1 e 2 - Saia pintada com os grafismos Kokama pelos adolescentes do Centro Cultural Mainuma, Parque das Tribos, Manaus, AM. Na barra da saia, em vermelho, o grafismo do casco de jabuti.

Fonte: Arquivo pessoal da pesquisadora.

A antropóloga Lux Vidal nos fala que os grafismos indígenas representam, tanto em nível ritual, quanto em nível cotidiano, "um sistema de comunicação visual estruturado capaz de simbolizar eventos, categorias e status e dotado de estreita relação com outros meios de comunicação verbais e não-verbais". (2000, p. 144). Para os ameríndios, os grafismos, assim como os artefatos, guardam e contam a história de suas origens ancestrais estabelecendo uma conexão espiritual com seus antepassados, cada etnia possui a sua gama de grafismos que são sua marca identitária.

Ouvi das mulheres indígenas do Parque das Tribos que os grafismos feitos de sumo de jenipapo que elas desenham em seus corpos são sagrados, têm uma função protetora e servem como maquiagem. 'O grafismo para nós é sagrado, é nossa maquiagem que nos protege e embeleza' (Mepaeruna). Do mesmo modo, os colares e outros adornos que usam no corpo e cabelo são considerados elementos que, além de as deixarem mais bonitas, as identificam enquanto pertencentes as suas etnias e transmitem informações a respeito daquela pessoa, que é reconhecida por quem compreende essa gama de signos.

Podemos perceber, pela fala de Mepaeruna, que os grafismos e artefatos possuem uma função social que ultrapassa a questão estética e fazem parte de saberes compartilhados através de uma rede de relações. Deste modo, a apreciação estética não é separada de um significado 
engendrado pelo contexto social a que pertence, grafismos e artefatos existem por uma rede de relações dentro da sociedade e agem sobre as pessoas. São manifestações que se apresentam com conteúdo ético e estético indissociáveis.

Nessa lógica, as fronteiras entre vida e arte não se definem de forma tão categórica, as coisas fluem de maneira mais orgânica, mesmo que existam objetos para serem utilizados e objetos para serem contemplados, eles possuem um significado de existência e relação com o ciclo da vida para as pessoas daquele povo, através de práticas que ritualizam sua existência.

Na realidade, os conceitos de arte e cultura são definidos a partir de nosso olhar de não indígenas e, ocasionalmente, apreendidos pelos indígenas como uma forma de tentar se aproximar do nosso pensamento. Els Lagrou (2009) nos faz pensar sobre isso, ao dizer que os indígenas não têm a mesma noção de arte e estética que nós e, muitas vezes, nem mesmo palavras ou conceitos para defini-la porque o que consideramos arte, a partir de nossas referências, são para eles objetos com funções específicas dentro de sua sociedade.

Fui convidada para atuar junto das professoras indígenas no Parque das Tribos a partir de minha experiência enquanto artista e professora - que elas conheciam - mas sempre refletimos sobre qual seria a melhor maneira de realizar uma prática que não passasse por cima dos ideais dos sujeitos envolvidos, até porque, a ideia de 'performatizar a cultura' (CUNHA, 2009) pode ser uma armadilha quando estamos trabalhando nesse contexto, muitas vezes, os indígenas tendem a nos mostrar e falar aquilo que imaginam que queremos ver e ouvir.

Todavia, percebo um grande processo de autonomia por parte dos indígenas no Parque das Tribos, especialmente os adultos e os jovens, digo isso, pelo fato de sempre trazerem proposições para a realização de nossas ações, sentindo-se à vontade em colaborar a respeito de como podemos realizá-las.

Foi enriquecedor para meu processo criativo, o fato de os adolescentes proporem a transformação de meu figurino para que dialogasse com a história dos mundos Kokama. Fazendo parte do processo eles se sentem valorizados, com orgulho de serem indígenas e mostrarem aquilo que é da sua 'cultura', como demonstram em suas falas e ações. Essa não foi a única proposição deles, ao final de cada encontro abríamos um espaço de conversa e os jovens sempre trouxeram contribuições significativas. As crianças ainda ficavam tímidas no início, mas aos poucos se tornaram mais participativas, até mesmo pela relação de confiança que foi se estabelecendo. Para tentarmos 
refletir sobre como as crianças estavam sentindo as experiências poéticas, já que muitas ainda não sabiam escrever e ficavam acanhadas em falar, disponibilizávamos folhas de ofício, lápis e giz de cera para que desenhassem algo relacionado ao que havíamos experimentado, assim, podíamos analisar os desenhos e ver os momentos mais marcantes e como elas reagiam às histórias e às atividades desenvolvidas.

As percepções das crianças e dos jovens nos ajudam a entender o processo que faz parte da afirmação da 'identidade cultural' (Vidal, 2000) deles enquanto indígenas. A questão identitária, de se reconhecerem pertencentes a suas etnias, proporciona a elevação de sua autoestima, porque convivendo nesse contexto percebemos o que sentem em relação ao preconceito que ainda existe vindo de uma grande parcela da população que desconhece como vivem os povos indígenas atualmente.

Podemos pensar sobre isso e sobre algumas questões que levantamos até aqui a partir da fala de Vanda, da etnia Witoto, moradora do Parque das Tribos e estudante do curso de Pedagogia da UEA, no encontro entre comunidades que realizamos na ESAT - UEA ${ }^{8}$. O evento, ocorrido em maio de 2018, foi intitulado 'Diálogo com as Mulheres Indígenas' e organizado pelos discentes do curso de Teatro: Jackeline Monteiro, Leandro Lopes e Valéria Batalha, que participam deste projeto que desenvolvemos no Parque das Tribos. Segue a fala de Vanda:

Eu vou ser professora indígena e dentro da universidade eu observo muitas coisas. Eu fui educada na visão portuguesa, por que meus avós sofrerem muito quando vieram da Colômbia, meus pais não foram educados na língua Witoto por causa do preconceito, só quem fala Witoto é minha avó e o meu avô, eles não queriam de jeito nenhum discutir isso com os filhos por conta de todo o sofrimento que tiveram lá, eu não fui educada e hoje eu aprendo minha língua. Na Colômbia ainda existe seis mil falantes de Witoto, meu sonho é entrar em contato com essa comunidade para que eu tenha esse contato maior com minha identidade. Dentro da própria universidade existe muito estereótipo indígena, e eu tenho tido a oportunidade de falar porque eu tenho me mostrado e tenho questionado alguns professores e tenho obtido alguns resultados e isso é muito importante: a comunidade acadêmica ouvir também o outro lado, lá dentro mesmo os discursos sobre ser índio, o que a gente aprende para falar para nossas crianças é algo muito superficial, sem conhecimento. É muito triste você abrir um livro e dizer para uma criança sobre um índio de 1500, só falam do índio de 1500, o que é um índio de 1500 que a história conta? vocês já se perguntaram se esse índio ainda existe? esse índio não existe mais, ele foi dizimado naquele período. Então muita coisa foi transformada dentro da nossa cultura, dentro da nossa vivência, dentro das nossas comunidades indígenas, tudo foi modificado, não existe aquele índio de 1500 mais. E assim, você transmitir como professor isso para as crianças é o que gera o preconceito que nós temos, a própria universidade transmite visões preconceituosas, até que ponto o que os livros trazem é real?! então a gente tem que se questionar muito quanto $a$ isso. Eu fico feliz por estar aqui, por poder falar o que eu penso.

\footnotetext{
${ }^{8}$ Escola de Artes e Turismo da Universidade do Estado do Amazonas.
} 


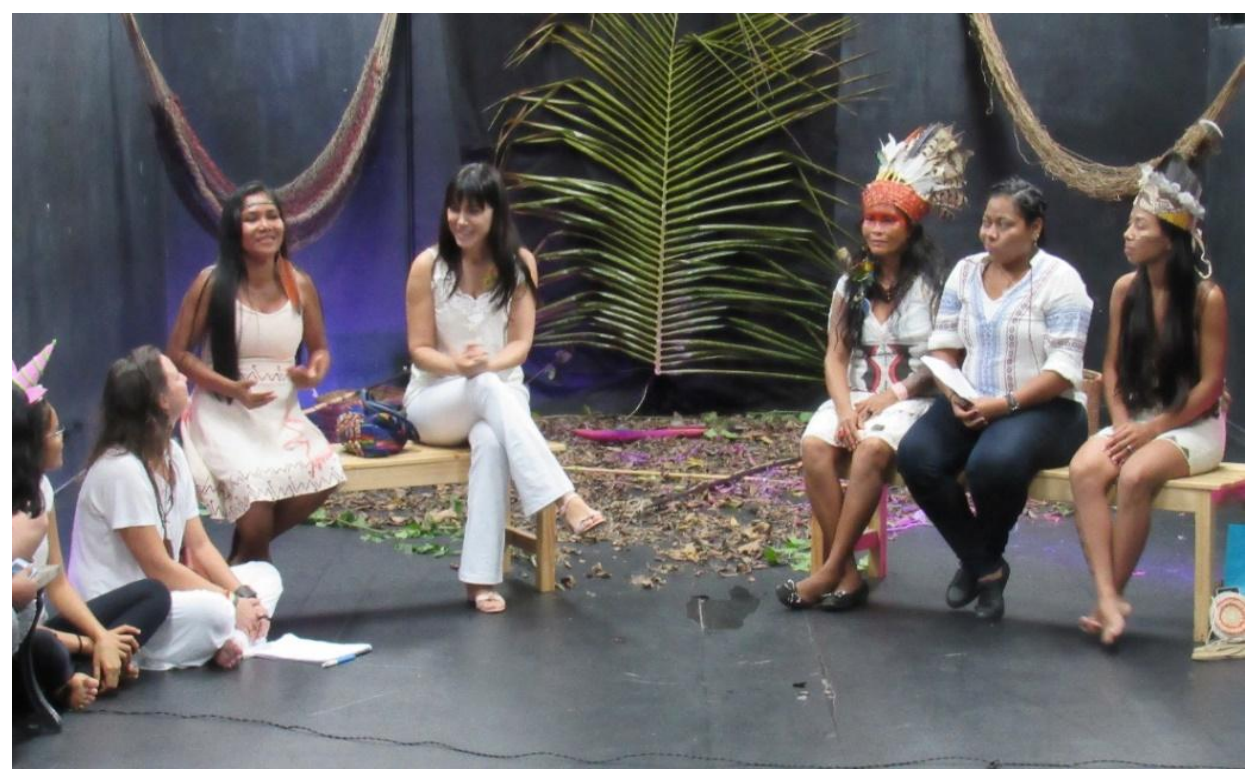

Figura 3 - 'Diálogo com as mulheres indígenas'. Sentadas nos bancos, a esquerda: Tsuni, eu, em seguida, no centro, a Cacique Lutana, ao seu lado Jackeline Monteiro - discente do curso de Licenciatura em Teatro da UEA, uma das organizadoras do evento - e a direita Vanda Witoto. ESAT (Escola de Comunicação e Artes) - UEA (Universidade do Estado do Amazonas), Manaus, AM.

Fonte: Arquivo pessoal da pesquisadora. 05/05/2018.

Cada vez mais existe um empoderamento por parte dos indígenas em se assumirem enquanto tais, utilizando as pinturas de grafismo no corpo, os colares, os cocares, enfim, tantos outros adereços que possuem e caracterizam suas etnias, como um ato de representatividade e resistência.

Da mesma forma, por serem conhecedores de toda a simbologia que os grafismos representam, percebo o sentimento de representatividade dos jovens do Centro Cultural Mainuma ao desenharem os grafismos em minha saia de contadora de histórias: 'Agora a saia da professora Vanessa é Kokama'.

Os grafismos são uma forma de comunicação reconhecida e valorizada como um meio constante de afirmação e reafirmação de um pensamento, princípios, valores, que agem sobre a realidade de acordo com o contexto em que estão inseridos. Um dos grafismos desenhados na saia é o do casco de jabuti, que segundo a Cacique Lutana Kokama funciona como um escudo protetor, já que o casco do jabuti tem como característica ser forte e resistente. O jabuti é a figura mitológica principal do imaginário Kokama, ele é utilizado em curas espirituais, na medicina e na gastronomia.

Abaixo alguns momentos do dia em que contei a história dos mundos Kokama. Em seguida, improvisamos a história com todo o grupo. Durante a improvisação sugeri que reproduzíssemos 
partes da história que tinham sido mais significativas, que fizéssemos as personagens, ou, quem quisesse poderia recontá-la à sua maneira. E assim, vivenciamos aquele encontro, com todos trazendo suas contribuições para performarmos aquela história.

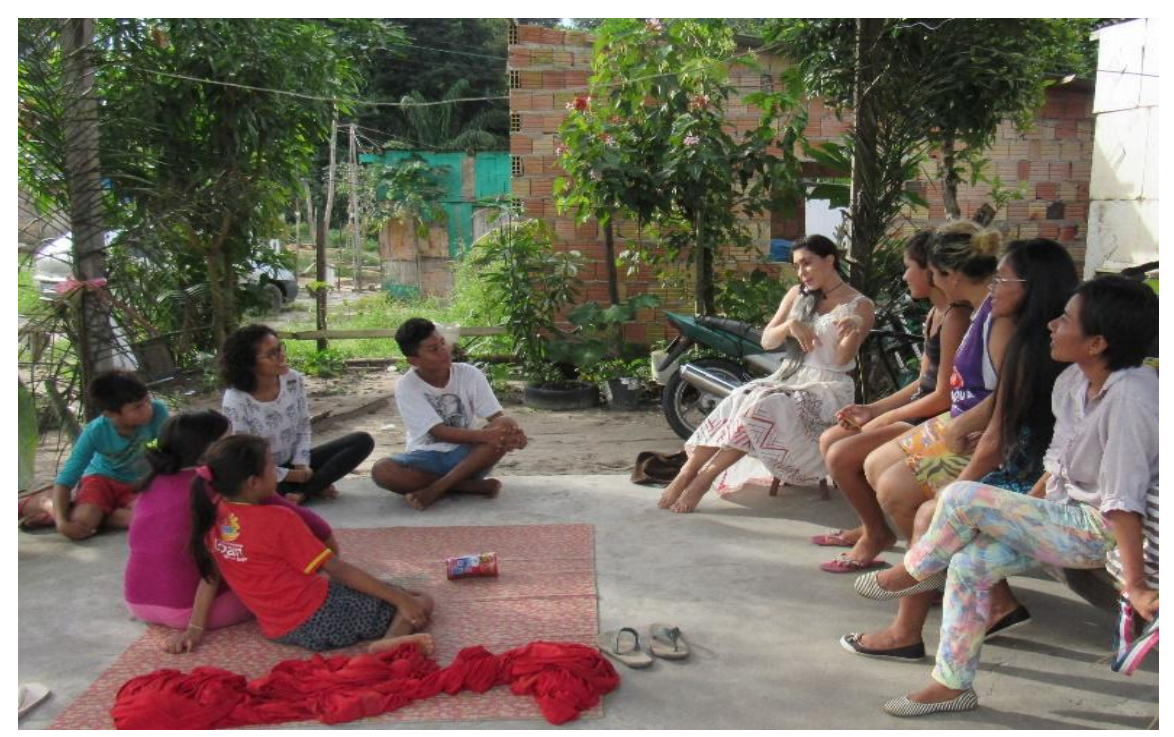

Figura 4 - Contando a história dos mundos Kokama. Centro Cultural Mainuma, Parque das Tribos, Manaus, AM. Fonte: Arquivo pessoal da pesquisadora. 14/04/2018.

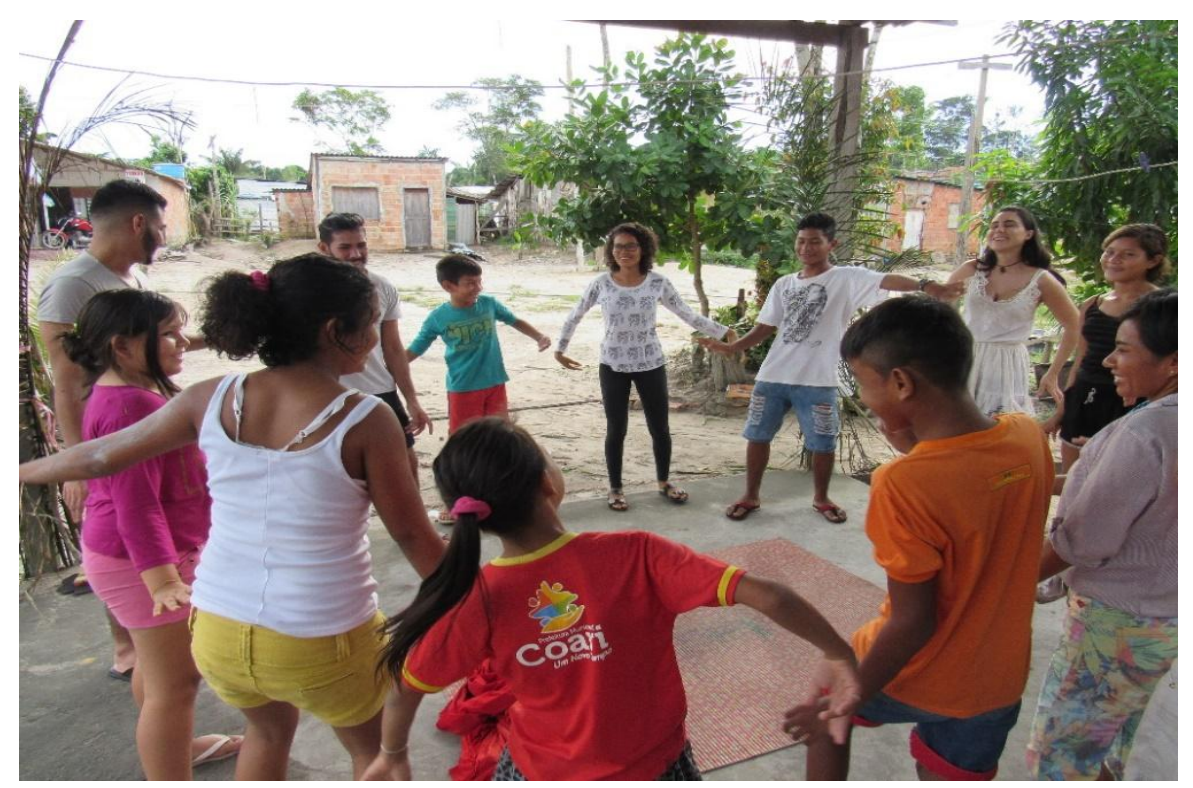

Figura 5 - Improvisação a partir da história dos mundos Kokama. Centro Cultural Mainuma, Parque das Tribos, Manaus, AM.

Fonte: Arquivo pessoal da pesquisadora. 14/04/2018.

Nesse universo, onde conhecemos, contamos, cantamos, criamos e recriamos histórias: histórias de nossos antepassados, histórias de outros povos e nossas histórias pessoais, é que 
vivenciamos um espaço de encontro, eu, junto de alguns discentes do Curso de Teatro da UEA, das professoras, das crianças e dos adolescentes indígenas na comunidade Parque das Tribos.

A proposta de Tsuni enquanto educadora indígena é de vitalização da língua e dos saberes Kokama. Performamos nesse espaço a partir das histórias e canções de seu povo, pensando em contribuir nesse processo ao estimular uma experiência criativa. Como aluna das aulas aprendo algumas palavras na língua e quando conto as histórias tento trazê-las, Tsuni acrescenta outras traduzindo do português para o Kokama.

A experiência sensível possibilitada pela prática artística tem por si só um cunho pedagógico, não precisando ser utilizada como uma 'ferramenta', ou como auxiliar de outras práticas pedagógicas, no caso aqui, poderia ser o ensino da língua Kokama. O que desejamos é que nossa prática artística dialogue nesse contexto, não somente levando propostas pré-estabelecidas, mas que possamos construir juntos a partir do que eles têm enquanto potencial criativo.

As canções que trabalhamos também são histórias, tanto que a palavra imintsara é a mesma usada para história, conto e canção. Tudo que falamos a respeito das histórias, que são um dos modos de produção de conhecimento, serve para as canções, como disse Tsuni: 'cada canção traz um ensinamento'. Por isso, o trabalho com as histórias é junto com as canções e não tem como dissociá-las, as histórias são contadas com música e dança, e as canções nos contam histórias.

As canções e as histórias nos permitem tecer o passado com o presente, contribuindo no aprendizado da língua por meio dos sons, com alguns diferentes dos que temos em português, por exemplo o glotal ${ }^{9}$. Além disso, identificamos peculiaridades nos tempos e nos ritmos das falas e das canções, justamente por colocarem nossa voz em registros que não estamos habituados.

Acreditamos que performar histórias estimula o espírito coletivo, auxiliando na convivência em sociedade, permitindo a reflexão sobre os conteúdos das histórias e novos pontos de vista, além de ativar a imaginação para contarmos e criarmos nossas próprias histórias, nos divertindo nesse espaço. A diversão é um dos pontos principais deste trabalho. É fundamental a criação de um espaço lúdico e de prazer para que o processo de ensino-aprendizagem aconteça, eu busco isso quando atuo com crianças, o brincar é um elemento primordial, pois estão vivendo a infância.

\section{Referências}

${ }^{9}$ Som cuja articulação influi a glote. 
CUNHA, Manuela Carneiro da. Cultura com aspas e outros ensaios. São Paulo: Cosacnaify, 2009.

HARTMANN, Luciana. Gestos, palavra e memória: performances de contadores de "causos". Florianópolis: Editora da UFSC. 2011.

LAGROU, Els. A fluidez da forma: arte, alteridade e agência em uma sociedade amazônica (Kaxinawa, Acre). Rio de Janeiro: Topbooks, 2007.

Arte indígena no Brasil: agência, alteridade e relação. Editor: Fernando Pedro da Silva; Coordenação: Fernando Pedro da Silva e Marília Andrés Ribeiro; Orientações Pedagógicas: Lucia Gouvêa Pimentel e William Resende Quintal. Belo Horizonte: Editora C / Arte, 2009.

LOPES, Elisabeth Silva. A performance da memória. Revista Sala Preta. São Paulo, USP, v. 9, 2010. . Repertórios de teatro, performance e política. Memorial apresentado ao Curso de Artes Cênicas da Escola de Comunicação e Artes da Universidade de São Paulo. Concurso público de livre docência na área de interpretação teatral. São Paulo, SP. 2018.

SCHECHNER, Richard. Performance Studies: the broad spectrum approach. In: The Performance Studies Reader. New York: Routledge, 2004.

SEEGER, Anthony; DAMATTA, Roberto \& VIVEIROS DE CASTRO, Eduardo, 1979. A construção da pessoa nas sociedades indígenas brasileiras. Boletim do Museu Nacional, n. 32, pp. 2-19, 1979.

TAYLOR, Diana. O arquivo e o repertório. Performance e memória. Belo Horizonte: UFMG, 2013.

VIDAL, Lux. Grafismo indígena: estudos de antropologia estética. 2a edição - São Paulo: Studio Nobel: Fapesp, 2000.

VIVEIROS DE CASTRO, Eduardo. Os pronomes cosmológicos e o perspectivismo ameríndio. Rio de Janeiro: Mana 2 (UFRJ), 1996.

METAFÍSICAS CANIBAIS: Elementos para uma antropologia

pós-estrutural. São Paulo: COSAC NAIF, 2015.

ZUMTHOR. Paul. Performance, recepção e leitura. 2ª ed. São Paulo: Cosac Naify, 2002.

Artigo submetido em 05/04/2020, e aceito em 14/12/2020. 